\title{
When do university students and graduates know what careers they want: A research-derived framework
}

\author{
Shelley Kinash ${ }^{1}$, Linda Crane ${ }^{1}$, John Capper ${ }^{2}$, Mark Young ${ }^{3}$ and Ashley Stark ${ }^{1}$ \\ skinash@bond.edu.au; Icrane@bond.edu.au; JCapper@divinity.edu.au; \\ m.young@latrobe.edu.au; astark@bond.edu.au \\ ${ }^{1}$ Bond University, ${ }^{2}$ The University of Divinity, ${ }^{3}$ La Trobe University
}

\begin{abstract}
This paper reports on research which was conducted to explore how university students and those who had graduated and been subsequently employed, made career decisions. Specifically, through interviews and focus group discussions with 22 university students and 28 graduates from Australian undergraduate and postgraduate courses in a variety of disciplines, four questions were explored: Do university students know their own desired postcourse employment, or in other words, what they want to be after graduation; if so, at what point in their student experience do they come to this decision; what elements come into play in university student career decision-making; and to what extent do students and graduates feel that their career decision-making is supported by their universities? Research was grounded in, and results aligned with, the 'chaos theory of careers.' The main findings were that at the enrolment-stage of university and during their studies, most students were pessimistic about their career outcomes and felt largely unsupported in identifying suitable career goals. However, the outcomes after graduation were unexpectedly positive in that, by this point most had identified career goals and were in careers they had desired. Most of the research participants who had been in their careers for an extended length of time were casual academics who were dissatisfied with their career progression and status. Although they had identified academic career goals and secured employment in their chosen industry, they were disappointed by continuous short-term contracts and what they perceived as poor career supports extended by their university employers. A 'university student and graduate careerknowledge framework' was derived. The key takeaway from this research was a set of recommendations for universities regarding how to better support students to make career choices.
\end{abstract}

Keywords: graduate employability, career development, transition, higher education, students, graduates, career choice

\section{Introduction}

Providing strategies and supports to ensure that graduates are employable has become a major priority of universities (Bennett, Richardson, \& MacKinnon, 2015; Brewer, Flavell, Harris, Davis, \& Bathgate, 2014; Brown \& Carasso, 2013; Jollands et. al., 2015; Kinash et al., 2015; Oliver, 2015). However from the students' perspective, perhaps universities are focussing on the wrong question. How can the services, strategies and approaches to 
improving employability be effective if students do not know what they want to be? Career development experts believe that selecting a particular career path and choosing the related education and training required for that path are important career developmental tasks associated with transitioning from adolescence to adulthood (Creed \& Hughes, 2012, p. 148). An emerging theme in the published graduate employability literature is that many students do not have a clear sense of career options and therefore can lack career goals (Daghbashyan \& Hårsman, 2014; Dias, 2011).

\section{Literature}

There are a number of studies which have explored the career choice and goals of university students. Creed and Hughes (2012) analysed the relationship between various career survey instruments completed by 130 first-year university students at one Australian institution. Their main findings were that career compromise (e.g., acceptance into a degree program that was not first choice) increased career distress and decreased perceptions of employability, but that supportive strategies such as career guidance and increasing self-presentation skills can buffer these effects (see also Sornapooman \& Fyfe, 2015). However the research methodology was restricted to psychometric instruments and did not inquire into how the students came to their course choices and/or how this related to their career choices. Wu, Tsai and Chen (2014) analysed data from 614 undergraduate science majors across 12 universities in Taiwan. Statistical analysis of instruments showed a positive relationship between career guidance, vocational self-concept and self-perceived employability, leading the researchers to conclude that universities should support career development, emphasising information about graduate occupations. Similar to Creed and Hughes (2012), the research methodology was to use psychometric instruments and did not inquire further into why the students chose science, what occupational choices they were making for graduate careers, and how they arrived at these decisions.

Researchers have surveyed and/or interviewed either students and/or those who have graduated from university undergraduate or postgraduate degrees to report motivations and patterns for course and/or career identification. Dias (2011) interviewed 30 students who enrolled in Electrical and Computer Engineering at one university in Portugal. Rated in order from most to least important, the students' motivations for choosing engineering as their course of study were: being an engineer, engineering as an interest, social mobility and finding a job. Giles, Ski and Vrdoljak (2009) analysed survey data from 1206 graduates (32 universities) from Australian postgraduate degrees in science, engineering or technology. The top three reasons for enrolment in a research postgraduate degree were said to be: benefit to future careers, enjoyment in learning and undertaking research, and interest in the subject matter. These researchers subsequently conducted 123 case studies revealing that one of the key motivational factors for enrolling was to commence an academic career.

\section{Context of the study}

The research presented in this paper builds-on and extends the significance of this body of empirical literature in three ways. First, both students and graduates were included to investigate multiple phases of the student/graduate/employee career journey. Second, students and graduates from multiple institutions across Australia, a wide range of disciplines and industries and from both undergraduate and postgraduate courses participated in this research so that diversity and complexity could be considered. Third, in-depth interviews and focus groups were conducted with students and graduates so that their experiences, thoughts and emotions were captured from their point of view.

The unique contribution of this research to the intersecting body of literature on graduate employability and career development is that the experiences, thoughts and emotions

Kinash, S., Crane, L., Capper, J., Young, M., \& Stark, A. (2017). When do university students and graduates know what careers they want: A research-derived framework. Journal of Teaching and Learning for Graduate Employability, 8(1), 3-21. 4 
described by students and graduates have been interpreted and applied to map a framework of university student and graduate career-knowledge. This framework is firmly grounded in the 'chaos theory of careers' (Pryor \& Bright, 2003). This theory includes four main elements which inform the framework presented in this paper - complexity, change, constructiveness, and chance (p.13). People, their various experiences, the employment context and therefore career decisions are complex with many variations of pathways, stops and starts. People change their mind: in the early stages of their course students may form a particular idea of what they want to do upon graduation but have an entirely different goal closer to graduation. Societies and cultures co-construct meanings and relative values of courses and careers. For example, students with the highest grades in high school often apply for medicine, law or engineering because these courses have the most rigorous entry standards and the associated careers have higher incomes and thereby status. During their studies (and other aspects of life that occur) students discover facets of themselves, such as social justice orientations, that shift and change these career goals. Finally, there is an element of chance in every career journey. For example, they happen upon an extra-curricular experience that changes their career goals or employment vacancies that were once abundant are no longer available and new industries and opportunities emerge, an aspect also supported by this study. Pryor and Bright wrote, ...the future is not somewhere a long way off, the future is emerging with each action we take and each response we make to changes in the complex dynamical systems of which we are a part or which intrude onto the fractal patterns of our lives (p. 18). Aligned with this theoretical orientation, the framework presented in this paper illustrates the complex and ever-changing routes of career decision-making of university students from application through graduation into careers.

\section{Research aims and methodology}

In 2014, research was conducted to inquire into Australian university graduate employability from the perspective of students, those who had graduated from undergraduate or postgraduate degrees (hereafter called 'graduates'), employers, educators and career development professionals (Kinash, et al., 2015). Interestingly, some findings which emerged were not hypothesised nor intentionally queried in the original data collection and analysis. It appeared from the data that students and graduates did not feel that they had a 'handle' on their career goals and were troubled by this uncertainty. Furthermore, they appeared to be critical of university student support for not providing what they perceived as needed career guidance. A secondary analysis of the original data was therefore conducted to explore the following questions:

1. Do university students know their own desired post-course employment, or in other words, what they want to be after graduation?

2. If so, at what point in their student experience do they come to this decision?

3. What elements come into play in university student career decision-making?

4. To what extent do students and graduates feel that their career decision-making is supported by their universities?

The chosen methodology for this research was hermeneutic phenomenology whereby interpretations were made based on exploration of the personal experiences described by students and graduates. Hermeneutic phenomenology is concerned with the underlying details of human experience as it is lived, aiming to achieve a sense of understanding and the establishment of salient themes (van Manen, 1997).

\section{Participants}

Interviews and focus groups were conducted with 22 university students and 28 graduates as part of a larger strategic research project about graduate employability commissioned by the

Kinash, S., Crane, L., Capper, J., Young, M., \& Stark, A. (2017). When do university students and graduates know what careers they want: A research-derived framework. Journal of Teaching and Learning for Graduate Employability, 8(1), 3-21. 5 
Australian Government, Department of Education and Training. In regards to sampling, purposive efforts were made to ensure research diversity, including multiple institutions, disciplines, employment type and gender. Research participants were recruited directly through researchers approaching students, graduates and employers at university career fairs and indirectly using educator and other higher education collegial contacts (i.e., staff referring their students and graduates). All recruitment, data collection and dissemination were conducted in strict adherence to approved ethical procedures through the lead institution. Information on participant demographic details is provided in Table 1.

Table 1: Participant Demographics

\begin{tabular}{|c|c|c|c|c|}
\hline Participant & Male & Female & Undergraduate & Postgraduate \\
\hline $\begin{array}{l}\text { Students } \\
(n=22)\end{array}$ & $\begin{array}{c}7 \\
(32 \%)\end{array}$ & $\begin{array}{c}15 \\
(68 \%)\end{array}$ & $\begin{array}{c}13 \\
(59 \%)\end{array}$ & $\begin{array}{c}9 \\
(41 \%)\end{array}$ \\
\hline $\begin{array}{l}\text { Graduates } \\
(n=28)\end{array}$ & $\begin{array}{c}14 \\
(50 \%)\end{array}$ & $\begin{array}{c}14 \\
(50 \%)\end{array}$ & $\mathrm{N} / \mathrm{A}$ & $\mathrm{N} / \mathrm{A}$ \\
\hline
\end{tabular}

As demonstrated in Table 2, students and graduates who participated in this study represented an overall total of nine different fields of study. Eight graduates were working for multi-national corporations, four in theology, three in universities, three as start-up entrepreneurs and two in the public service.

Table 2: Participant Fields of Study

\begin{tabular}{|c|c|c|c|c|c|c|c|c|c|}
\hline Participant & Law & Business & IR & Arts & $\begin{array}{c}\text { Food } \\
\text { Sciences }\end{array}$ & Divinity & IT & $\begin{array}{l}\text { Engineer- } \\
\text { ing }\end{array}$ & Research \\
\hline $\begin{array}{l}\text { Students } \\
(n=22)\end{array}$ & 7 & 6 & 1 & 5 & 4 & 0 & 0 & 0 & 2 \\
\hline $\begin{array}{l}\text { Graduates } \\
(n=28)\end{array}$ & 2 & 5 & 0 & 7 & 1 & 4 & 2 & 6 & 1 \\
\hline
\end{tabular}

Note. IR = International Relations. IT = Information Technology. Some students studied across multiple fields, so the overall total will not add up to the original sample size of 22.

\section{Data Collection}

Interviews and focus groups were a maximum of one-hour in length. They were conducted as interactive interviews whereby a set of questions was used as a starting point, but allowed, following the lead of research participants, for emerging themes (Ellis, Kiesinger, \& TillmanHealy, 1997). Few questions were asked directly about career identification and identity so that themes emerged out of the data rather than responses being led. Sample questions/probes included: what opportunities does/did your university provide you to enhance your graduate employability; what is good about the graduate employability supports your university offers/offered; and what should be improved about these graduate employability supports. 
Analysis

Multiple interpretive lenses were used for the secondary analysis reported in this paper, including using unstructured discourse analysis (Alvesson \& Sköldberg, 2000). This interpretative approach provided particular data probes: How the research participants responded and the order in which their responses emerged are informative. Which descriptors within the questions were most salient in the responses of which participants? (Kinash, 2006). Furthermore, using the analytic approach of Shaddock (2014) each full transcript was manually thematically analysed independently by two of the researchers. A third researcher confirmed 80 per cent agreement between the thematic codes and frames and created a master analysis.

\section{Results}

\section{University entry}

Many of the students commented on their state-of-mind upon entering university. With regard to this most of the students who commented said that upon enrolment, they did not have a specific career goal or a sense of what courses would lead to what careers, but that they desired this knowledge. Career services did not appear to have been extended to any of the students prior to, or early after, enrolment. One of the students, reflecting on the way in which advising is currently structured, commented as follows:

...we'd have to know that from the beginning, what we want to do, otherwise career supports aren't going to help.'

Among the few students who expressed that they started university with a specific goal, they indicated that their choices were influenced by family as opposed to guidance from the education system. Sometimes the family influence was perceived positively, such as the Aboriginal student who said that his decision to pursue education as a discipline was inspired by family explaining:

...having that positive support, positive role model in my life who pushed me to go on and be a teacher where I could go back and work with my mob and empower them through education.

For other students, the familiarity of family influence was perceived as limiting. One student explained her course-change being family career-related:

\section{I started originally in hospitality because the majority of my family is coming from that background.'}

Many students expressed a desire for personalised career counselling prior to university enrolment. These students said that they would have liked combined course/career advice. A few students specified that they would have liked a career advisor getting to know them and then suggesting careers that might suit their strengths and passions, and finally, advising which courses could be expected to lead to those careers.

Other students said that they should not be expected to choose careers, and thereby courses, prior to university enrolment. These students said that they would have benefitted from a smorgasbord approach to their first-year where they tried various options prior to making a decision. Furthermore, these students said that for this model to work, first-year university subjects would need to be aligned with career skills so that students could make informed career choices based on the roles and responsibilities they would actually be undertaking upon graduation. For example, one student commented: 
whether or not it's actually what you want to do, rather than taking classes and just learning in the classroom and then going into the workforce.' Another student said, 'But I think it needs to be more that ... you should be doing different disciplines and hard skills at a young age. People I think would have a better sense of what they actually like and what they want to do in the future.

\section{During university}

The expressed indecision about career options at the point of enrolment seems to have continued into the degree for many students, and throughout the entire degree to the point of graduation for some. For example, one student who had appeared to have made up his mind as the degree progressed said that he wished that he had identified his goals sooner with the following comment.

Looking back, I probably should have been focused a bit earlier ... but wasn't largely because I didn't really have a clear idea of what I wanted to do specifically at that stage.'

Others expressed that they were close to graduation and still didn't know what they wanted to be.

A theme pursued by a number of students was re-defining their identities alongside making career choices. One student happily shifted into an altruistic path, commenting:

If you met me a year ago, I was a completely different person. Social contribution was not something I was interested in. I was interested in success, money, that's it. Then I [got involved in] a leadership development organisation.

For other students, the reverse occurred and these students expressed a sense of loss:

I am currently being forced into moulding myself to be just in the same line as everybody.

A mature-age student said,

We wanted to be global citizens and didn't want to be working for the man. ... we were attracted to working for the United Nations ... so we're all probably in our 30s right now feeling a little bit disgruntled.'

Part of the students' indecision about career pathways appears to be connected to insecurity about getting hired. In other words, students questioned whether they had wisely chosen courses and associated careers in the face of graduate unemployment rates. When asked whether they expected to be employed in the discipline of study, only two students replied with a confident and unqualified 'yes'. Five students were not asked because they were already employed, two in entrepreneurial capacities. Five others replied 'no'. The remaining ten students were not sure. Overall, participants had a highly emotive response to this question, expressing themselves with comments such as these:

It's so scary to think that you won't get a job in that industry.

I wouldn't accept a job that was totally different but I would be willing to accept something that is not ideal for the moment and just to work to get that later.

The three Bachelor of Arts students were among those replying 'no' and they explained that initially they were not 'disillusioned' because each had chosen his or her degree just to follow an interest, but as graduation was looming, each was increasingly concerned. Two of the arts student commented as follows:

I found out half way through that it wasn't going to advance my job opportunities. 
I've changed my mind twice since I started the diploma and then I thought 'No this is ridiculous, I'll do a Bachelor' and then, 'Now what am I going to do?' and then realise that what I picked as a major is not really going to be that suitable. Well, who's going to employ me? Throughout the time you're always evolving what you're going to do in the end.

A few students expressed that they were so concerned about graduate unemployment that they were contemplating stepping-out of the career journey by continuing as a perpetual student or giving-up on university altogether, for example:

I should be graduating sometime very soon ... but l'm in the process of changing my mind. I'm not sure if I'm going to continue or not because l'm finding searching for a job very daunting.'

If you're a mature age student you get to the end and think, 'Well l've only got this amount of years that I'm employable and I might as well just keep studying-nobody is going to give me a job.

There were some students who expressed that while taking their degree, they had clearly identified their career goals. One student explained that her career decision-making came about through experiencing the curriculum and content in this way:

I went to a guest lecture once and she said she did work with barnacles and I wouldn't have even thought that's possible but it's good to find out all these weird career pathways that you wouldn't even fathom just going to day to day classes.'

Another student shared a more personally structured route to his decision.

I just took a step back and re-evaluated what I was doing and for the first time in my life I actually wrote down my goals and where I want to be, and so I just started seeking opportunities.

This theme of 'doing it for oneself' was expressed by a number of other students. For example:

l'd say every sort of practical achievement l've gained during these years in university has been by me saying, 'Look, I need to take control of what l'm doing'.

I did have a careers advisor ... but it was more or less up to me, which was really super daunting because l've been a mother all of my life and haven't worked, just part-time jobs here and there, and then a university degree, and so l'm thinking, 'How do I adapt what I've just learnt to try and get a job ... as I haven't really had any experience.'

Students were vocal that they did not feel that they had been supported to make and achieve career goals through university student services commenting as follows:

I think that to be honest I think that the general careers and employability kind of department at the university is not that good. ... Maybe they could have different people who specialize in specific areas. ... He didn't have any specific information and he didn't seem to have any contacts or anything in industry.

It's up to us to apply straight to these people, where I think it would be nice to get the help from the hub and say, "Okay l'm interested in doing this particular job, how do I go about it? Can you give me more information on the actual employer, what they're looking for? 
Other students made suggestions for a way forward:

Universities need to find a balance between stepping back and letting the individual do what they want and sitting on your shoulder and saying you should be doing this now, you should be doing that. Still give you the room to sort of look around but also nudge you every now and then.

In an ideal world it would be good if they had for example if this particular cohort came in, they had a set of people sort of tracking their degrees so you could sort of get that bump like, 'Hey you're at the point now where you should try to get some work experience.'

Student wish-lists for student career services appeared to be more discipline/industry specialisation and knowledge, as well as shifting some of the career identification and job search responsibilities onto the staff rather than the students.

\section{Early career}

Whereas few students expected their careers to be directly related to their degrees, notably seventeen $(61 \%)$ of the graduates perceived that their degrees were indeed related. One of the graduates said, I am very happy. It was what I was aiming for. Disconnect between degree discipline and career industry appeared to be course-related. The two arts graduates were among those who stated that their careers were unrelated to their studies. Several of the postgraduates had completed bachelor's degrees in the arts, and then masters or PhDs in areas where they said that they felt more secure about gaining employment. One graduate explained that she did not 'regret' studying arts as an undergraduate but did not want to be 'left at the bottom of the career food-chain' and thereby pursued a postgraduate degree in law.

The majority of graduates were reasonably satisfied in what, for most, were early careers. Those working for multi-national corporations and the public service were highly satisfied with the formalised early career supports and rotations put into place for them. Those engaged in theological pursuits expressed a spiritual cohesiveness in pursuing their callings. Entrepreneurs were enthusiastic and optimistic, but had not yet achieved financial viability (i.e. the start-up endeavours were not paying their salaries). Those who were least satisfied were those employed by universities. These graduates said that they had aspired to full-time academic careers. One 'resigned' himself to a professional staff position. Another 'piecedtogether' contracts at multiple universities.

\section{During careers}

Within this research, the participants who had graduated quite some time before and had been working in their careers since, were mainly working in universities. They were mostly dissatisfied with universities as employers, working conditions and staff career supports. Some were re-evaluating their career options and goals. One research participant had been working at the same university for ten years and was vocally disgruntled. She was pursuing her PhD but did not hold any optimism that this would change her employment status. She said that for ten years she was forced to work multiple pieced-together three-month contracts and sustain fears of an insecure financial future. She said:

I would go anywhere where there's a permanent position. However, I've been told by the workforce that I'm unemployable because of discrete disciplinary expertise so I've spent 10 years perfecting a CV that's suited to academia, which essentially, I'm told that I can't even get a job answering phones with.

She was clearly unhappy about university supports in her transition from study to an academic career. While her views were the strongest among those interviewed, this view was common

Kinash, S., Crane, L., Capper, J., Young, M., \& Stark, A. (2017). When do university students and graduates know what careers they want: A research-derived framework. Journal of Teaching and Learning for Graduate Employability, 8(1), 3-21. 10 
to all of the interviewed graduates who wanted to pursue academic careers. She further commented:

When you're graduating as a social scientist, you're basically graduating as an academic. There was essentially no career development that takes you from your degree into academia. Other than pushing someone off a cliff.

\section{Discussion}

Shared experiences and patterns emerged in the students' and graduates' descriptions of their career decision-making (depicted as a framework in Figure 1 below). While the students' and graduates' described experiences clearly clustered into four phases (university entry, during university, early career and during careers), beyond this structure, the other elements of career decision-making were highly variable and individual. As described by Borg, Bright and Pryor (2006) careers rarely follow logical and linear paths, especially modern careers (p. 57). Just as careers do not follow clear, structured paths, the descriptions shared by the students and graduates in this research, indicated that neither do career decisions. The unpredictable experiences and unforeseen events shared by the participating students and graduates in this research is consistent with the findings of Borg and colleagues. For example, one of the interviewed students in this research described joining a leadership development organisation. This student described this involvement as entirely changing his career goals and perspective. The framework presented below therefore includes the words 'and life' in the experiential boxes alongside university 'courses' and 'subsequent study' during careers. The 'and life' addition recognises that there is no clear separation between the university student experience or within one's career and other aspects such as family, friendships and social activities. As can be seen in the complex responses of students to career decision-making, each of these contexts and the interplay between them can shift the students' and graduates' ideas and goals.

Returning to the structure of the four phases of career decision making, the first phase described by the research project participants was 'university entry' represented in the model as 'student enters course.' The students in this research stated that they expected a contribution from universities at this point where they are given 'pre course advice' that would relate to career outcomes and influence their career decision-making. The framework features a double-sided arrow between 'pre course advice' and 'student enters course' because the students expressed a desire for career information that would help them decide which course to select and then once they had selected the course, they wanted further advice, as their awareness of career opportunities and options expanded. At this point the framework is aspirational rather than descriptive in that students expressed that they were not provided with career-related 'pre course advice' either before or after they had chosen an academic discipline. In other words, at the current time, the double-sided arrow between 'pre course advice' and 'student enters course' should be visually depicted as broken or blocked, as the students participating in this research do not believe that they were provided with any careerrelated advice that would aid their decision as to which course to choose.

The framework continues to a decision-tree whereby the response to the question of whether the 'student knows own desired post-course outcome' is 'yes,' 'no,' or 'uncertain.' Many of the students participating in this research were clear that this early career direction is important to them. The participating students said that they acknowledged that career goals shift and change, but they wanted clearer information about the likely career outcomes from prospective universities before they decided on a university and a course. They wanted the focus and security of an initial goal. In other words, the most common framework pattern for these research participants was that 'no' they did not 'know own desired post-course outcome.'

Kinash, S., Crane, L., Capper, J., Young, M., \& Stark, A. (2017). When do university students and graduates know what careers they want: A research-derived framework. Journal of Teaching and Learning for Graduate Employability, 8(1), 3-21. 11 
The journey as depicted by the framework continues, in that regardless of whether the students start out with articulated career-goals, they are in the context of 'course and life' that further shapes their decisions (Dias, 2011; Pryor \& Bright, 2003). The students in this research said that both their course and life experiences influenced their career choices. Sometimes this was perceived positively and sometimes negatively. For example, one student felt that his course was not inspiring him towards leadership and change, but instead, that his learning experience meant being forced into moulding myself to be just in the same line as everybody. As described in the results section, another student talked about being a mother and how this influenced her career choices. As depicted in the framework, students who entered their course knowing 'own desired post course outcome' can shift into no longer knowing or uncertainty, students who started out with no clear career goals might have found them or moved to a middle ground, and so forth. The most common framework pathway for these students was to stay or arrive at the 'no' in regards to whether the 'student knows own desired post course employment.' The desired stimulus from the university at this point is careerrelated 'during course advice.' The university structures experienced by the students participating in this research appear to have given students the impression that it was the mandate of formal career advisors (as opposed to their educators, heads of school or other such faculty-based roles) to give students 'during course advice.' Many of the students complained that they did not find this advice helpful and the most common concerns were that advice was prescriptive or passive rather than instrumental and that it was not course or industry specific.

The next phase, as described by the research participants and depicted by the framework, is early career or after graduation, where the student enters 'post course employment.' The various pathways and arrows chart the journeys of the participating students and graduates in that a few expressed that they knew their 'own desired post course employment' prior to entering the course, stayed on that pathway throughout their course and despite intervening life circumstances, and then followed the 'enters expected post course employment' pathway. Some of the students in this research continued on this pathway during their career and even though they changed employers, engaged in subsequent informal and formal postgraduate studies and experienced various life circumstances, they 'continued in the same career.' However, this straight-forward pathway was less common among the graduates participating in this research. The pathway that more graduates had appeared to have travelled was not 'knowing their own post course employment' upon course entry and continuing as uncertain during the course. Positively, the majority of research participants who had graduated said that they had successfully attained employment and that their careers were of their choosing and therefore in their selected discipline. The early career part of the journey therefore appeared to be a turning-point in the student-graduate career cycle. Not all of the participants who were able to discuss the 'during career' phase were as satisfied. These participants were working in academic careers and the progression of their careers was not to their choosing.

The final factor depicted on the framework is 'vocational guidance'. The participating students who secured employment with a multi-national corporation or other such large businesses were particularly satisfied by the 'vocational guidance' provided by structured graduate employment programs or initiatives. Some graduates, for example, described moving through rotations and trying out different departments, teams and roles which they said greatly supported their within-career decision making regarding specialisations. The employees who were least satisfied with 'vocational guidance' were those working for universities, which were described as offering no career advice or support. The irony did not escape some of the research participants, in that the universities, which they conceptualised largely as provided career-relevant education, were in their estimation the weakest employers, in that they do not appear to provide ongoing 'vocational guidance' to their employees.

Kinash, S., Crane, L., Capper, J., Young, M., \& Stark, A. (2017). When do university students and graduates know what careers they want: A research-derived framework. Journal of Teaching and Learning for Graduate Employability, 8(1), 3-21. 12 


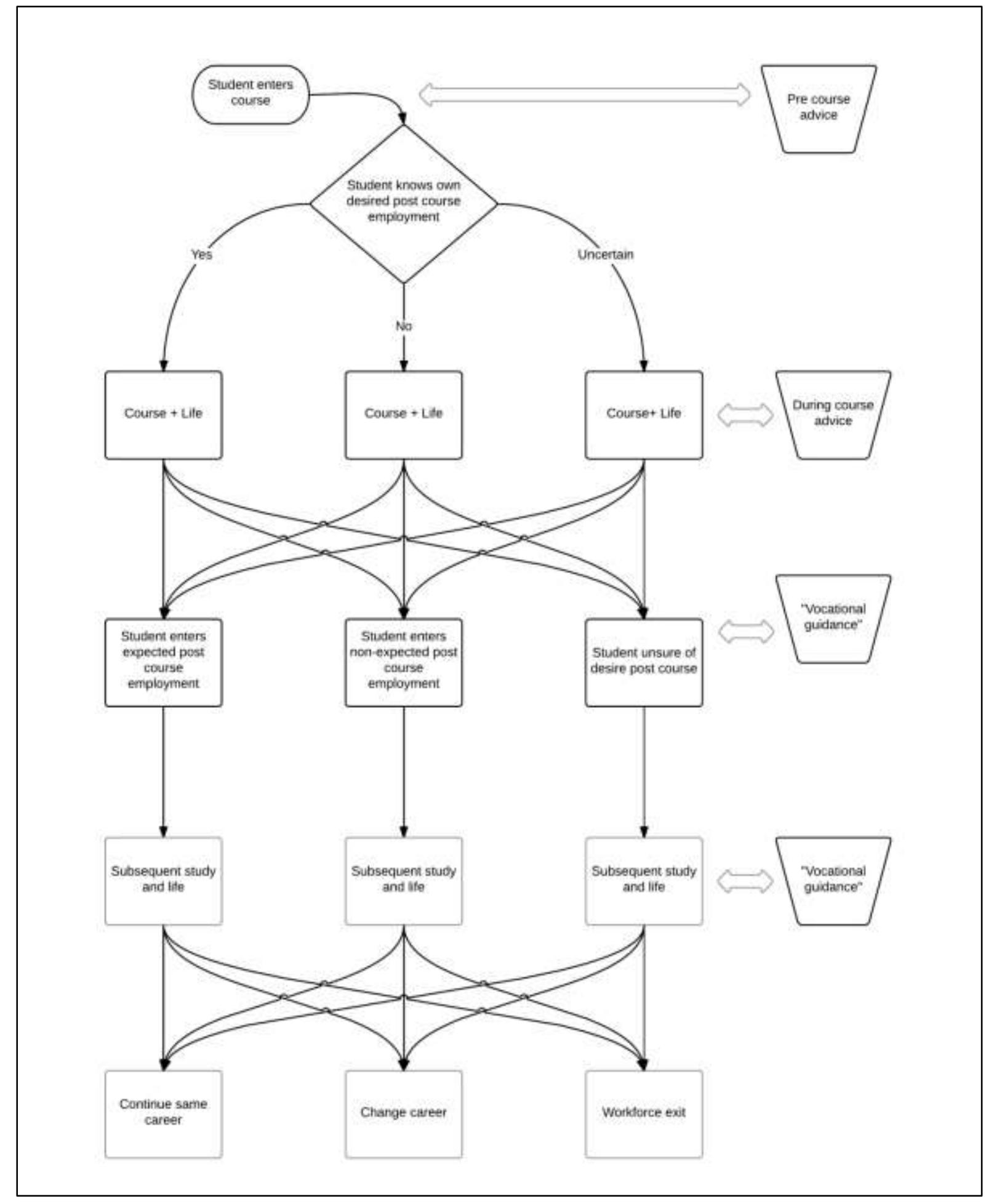

Figure 1: University Student and Graduate Career-Knowledge Framework

In the following section of the paper, each framework phase is described in greater detail, aligning career theory with the outcomes of this research.

Kinash, S., Crane, L., Capper, J., Young, M., \& Stark, A. (2017). When do university students and graduates know what careers they want: A research-derived framework. Journal of Teaching and Learning for Graduate Employability, 8(1), 3-21. 13 


\section{University entry}

The current system in most parts of Australia is structured such that students are expected to make a career choice while still in high school and then apply for direct entry into a course that will lead to that career option, or cluster of options. As reported in the results section, one student explained, we'd have to know that from the beginning, what we want to do, otherwise career supports aren't going to help. Creed and Hughes (2012) further explained, In Australia, university students apply for university entry in the year prior to admission. Typically, they would think about the occupation they want, explore the university courses that would progress their occupational goals, and rank order their desired courses on their application form ( $p$. 153). For some participants in this research, that pathway was fairly straight-forward, such as for the six engineering graduates. For others, such as the twelve arts students and graduates, the career options, opportunities and pathways were less obvious, and from the students' perspectives, their related anxiety increased the closer they came to graduation. Furthermore, beyond the type of degree, the research participants described other factors that complicated their career decision making. These reported factors were consistent with those described by Creed and Hughes: For some students, the transition can be straightforward ... For many, however, the process is more complicated ... Students might not be accepted into their most desired university or university course, might experience family pressure to follow a particular path, might not manage or like their course, or might develop doubts and new ideas resulting from their experiences and personal maturation (p. 153-154). Students participating in this research described these and other transitional factors. For example, as quoted in the results section, one student said, I started originally in hospitality because the majority of my family is coming from that background. He appeared to choose a familiar family-based pathway and then change upon enrolling and learning more about himself and other career options. In order to progress to these transitional factors, the future student is expected to start with an initial career goal (Dias, 2011). Most of the students participating in this research said that they did not feel that they were adequately supported and equipped with career-outcome knowledge to make their respective course selections. The university entry phase of the careerknowledge journey is depicted in Figure 2 as part of the overall framework.

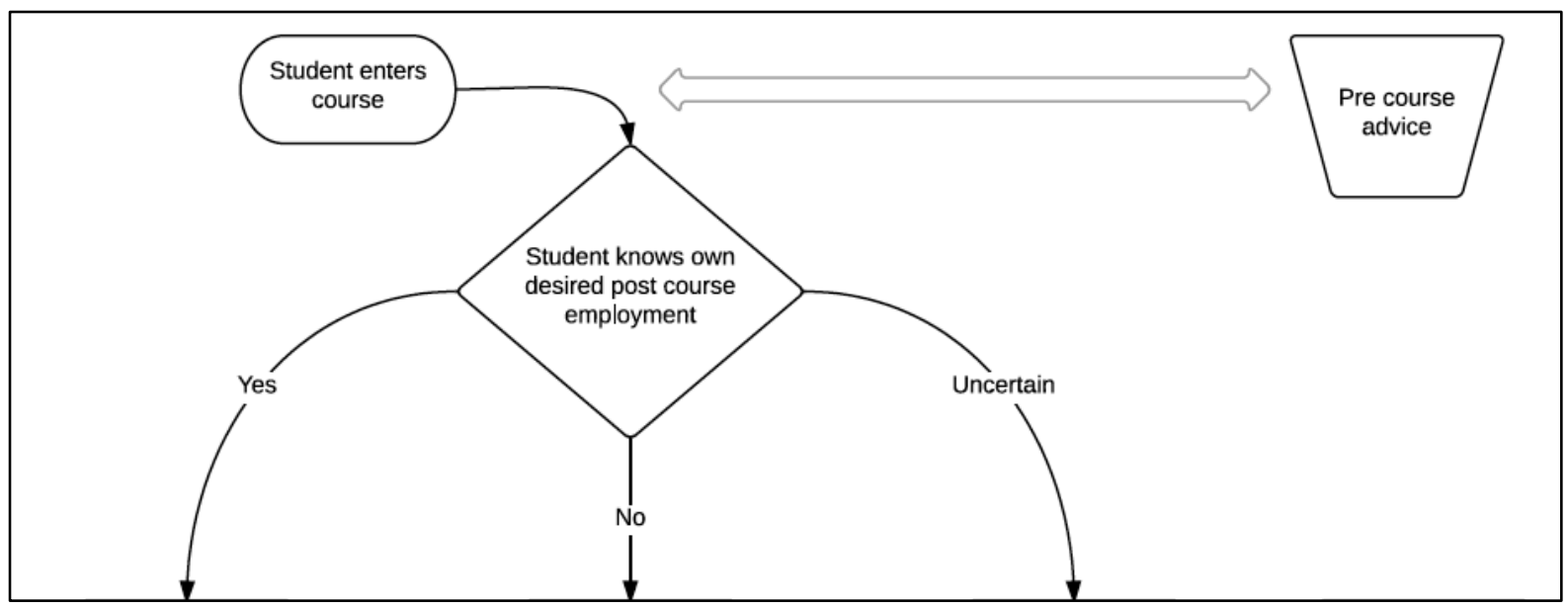

Figure 2: Career-Knowledge Framework: Phase One - University Entry 


\section{During university}

There are many processes at play during a student's trajectory through a course that inform and can further graduate employability. It appears as though advising, real life scenarios and activities, engagement and placements, and integration of formal learning and personal maturation allow for a more integrated approach for students in considering post course employment (Bennett et al., 2015; Brewer et al., 2014; Brown \& Carasso, 2013; Jollands, et.al., 2015; Kinash et al., 2015; Oliver, 2015). For example, a number of the interviewed students and graduates commented on the impact of a single 'accidental' subject such as business planning; the conversations and developed networks through this single subject were experienced as clearing what some described as 'clouds' of confusion regarding careers.

As expressed by research participants, much advice about post study employment derived from random anecdotes in class, advice from family and friends, and observations in part time employment and extra-curricular activities. A strong emergent theme was that during-course advice was often advertised as available through university career centres, but was not accessed by students until late in their studies, or not at all. Many of the interviewed students and graduates appeared to focus so much on the end of study that they paid minimal attention to post-study life, job searching or career counselling. These patterns of career-development experiences and decisions during university are depicted in Figure 3.

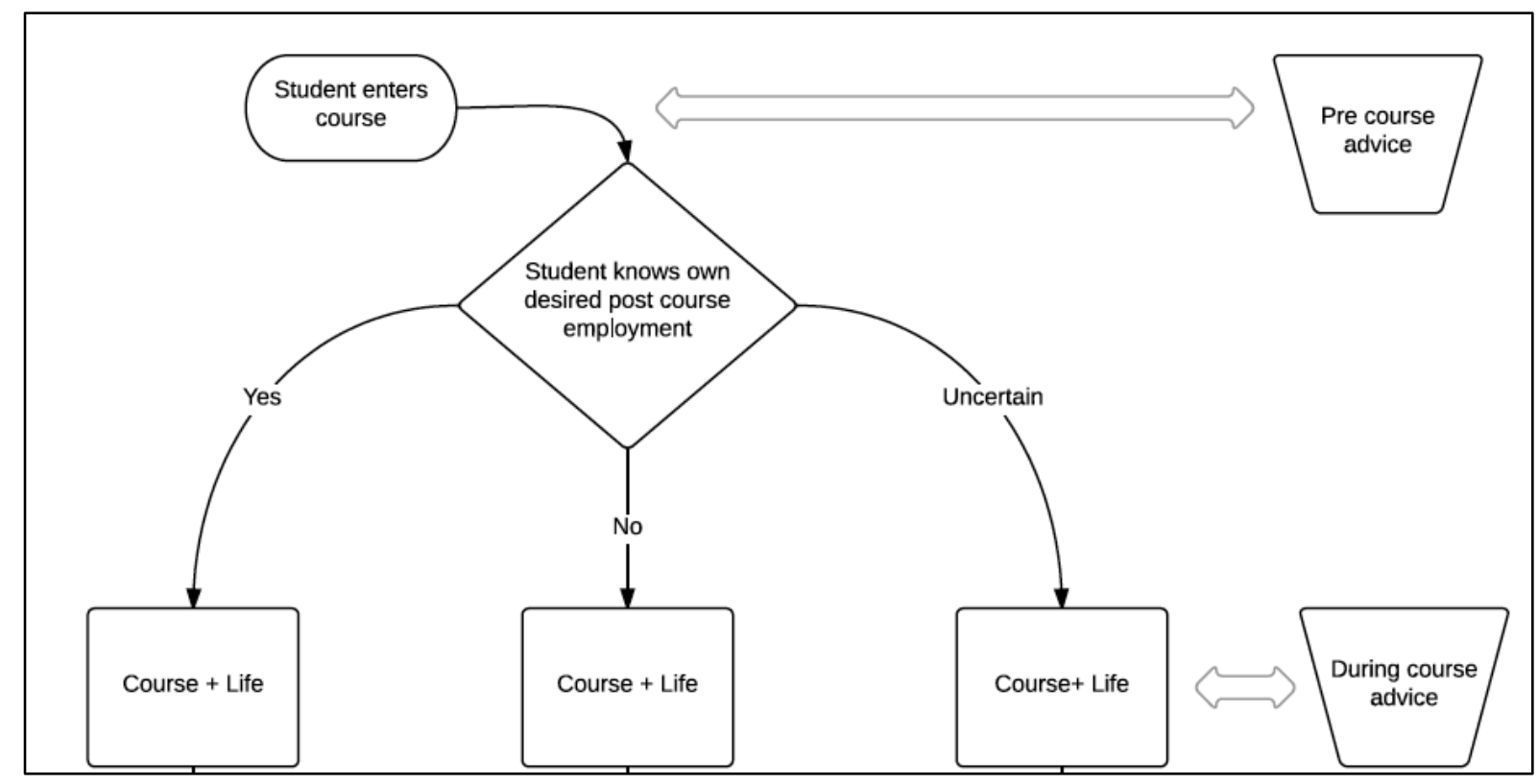

Figure 3: Career-Knowledge Framework: Phase Two - During University

\section{Early career}

As presented above, after appearing to experience career anxiety as students, the majority of graduates who participated in this research expressed satisfaction in their careers and appeared to be relieved (and somewhat surprised) that they managed to obtain careers of their choosing. Notably, this outcome was consistent with that found by Giles, Ski and Vrdoljak (2009). These unpredicted outcomes may be because students and graduates are not aware of what researchers such as Caballero and Walker (2010) have found to be the case in that employers are prepared to hire graduates who do not have expertise, or even experience, in specific fields or competencies, but show overall potential and thereby positive graduate 
attributes. These researchers wrote, 'graduates are often selected for their perceived general potential, rather than for a specific role within the company' (p. 15). In other words, whereas students may believe that they need to choose a specific role and job title and then learn and develop skills and competencies that make them employable, many employers appear willing to recruit based on more generic eligibility criteria and then train for particular specialisations. The early career experiences of university graduates are depicted in Figure 4.

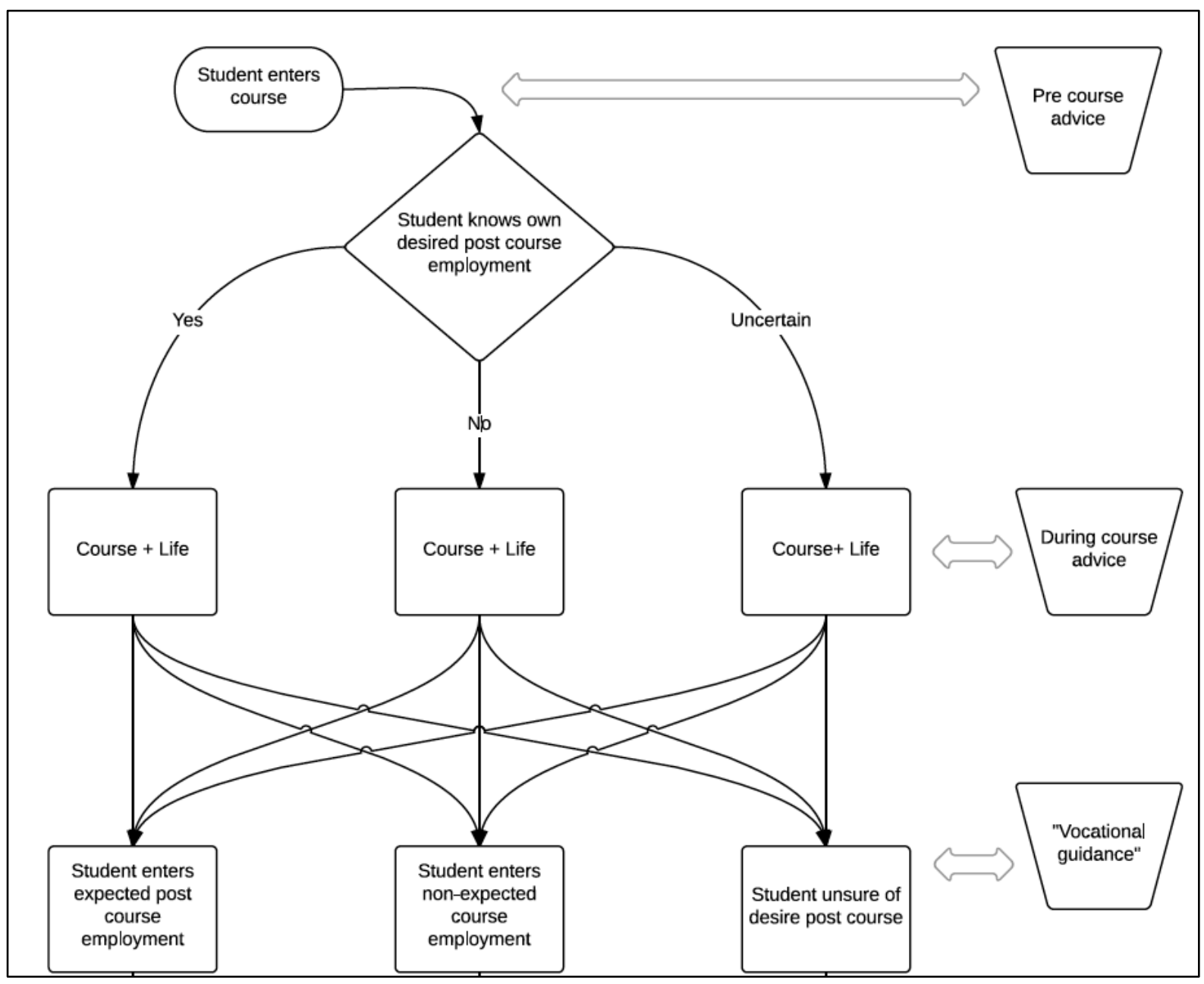

Figure 4: Career-Knowledge Framework: Phase Three - Early Career

\section{During careers}

As stated in the results section, the majority of the research participants who were beyond the 'early' stage of their career journey were casual academics. Their dissatisfaction with the conditions and status of their employment in terms of repeated short-term contracts was consistent with what is reported in the literature by researchers such as Giles et al., (2009). Many of the postgraduates in their research had enrolled to pursue academic careers and most 'moved from job to job on short-term contracts' (p. 82). Furthermore, the research participants commented on the '....highly divisive nature of short-term contracts: a two-tier system is created not only of opportunities and expectations but also of perceived personal worth and value' (p. 83). One of the deleterious consequences of the casualisation of the Australian academic workforce (beyond the negative impact on employee self-esteem and

Kinash, S., Crane, L., Capper, J., Young, M., \& Stark, A. (2017). When do university students and graduates know what careers they want: A research-derived framework. Journal of Teaching and Learning for Graduate Employability, 8(1), 3-21. 16 
quality of life) is what is commonly known as 'brain-drain.' Among the sample of 1206 graduates from Australian postgraduate studies in science, engineering and technology in the study by Giles et al., (2009), one third reported moving overseas at least for some time to further their career. Mentoring was revealed as a key ameliorative strategy, in that among the 123 case study participants, those who received formal, quality mentoring reported achieving greater career progression and quality career experience. During their careers, the students in the research reported in this paper had similar experiences to those reported in other studies and are depicted in Figure 5.

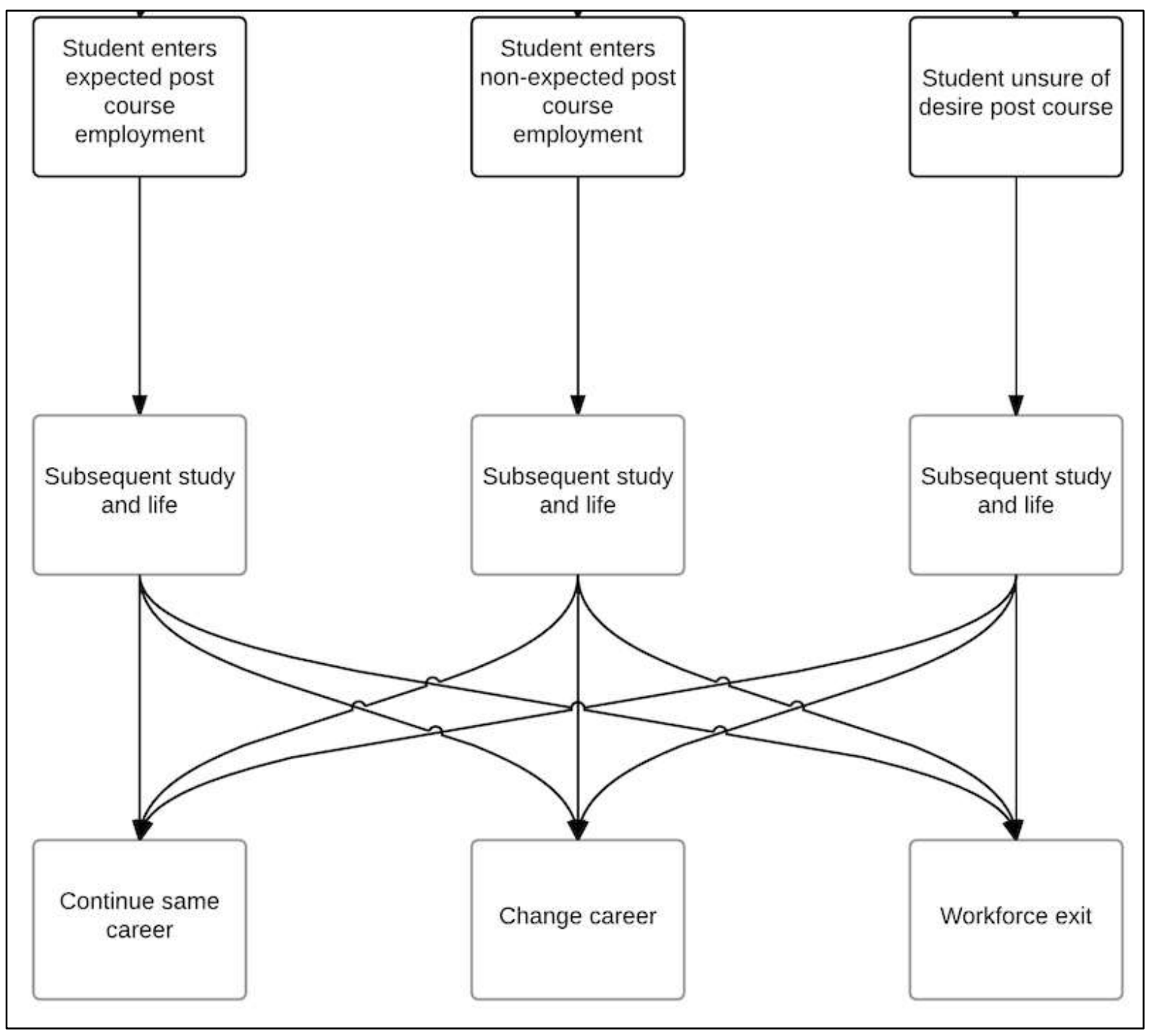

Figure 5: Career-Knowledge Framework: Phase Four - During Careers 


\section{Conclusion}

The data analysis of this study has revealed that most of the participants in this research did not clearly know their own desired post-course employment goals until graduation and were then positively surprised that their first careers were consistent with their choices. The elements that came into play in their decision-making were consistent with the chaos theory of careers including complexity, change, constructiveness and chance. The students' and graduates' career decision-making journey including the theorised elements were mapped to derive a university student and graduate career-knowledge framework. Overall, students and graduates did not feel that their career decision-making was appropriately supported by their universities. A key theme was that students felt that they needed, and did not receive, career advice prior to course selection. The highest emotive response came from graduates now working as casual academics for universities-as-employers. They did not feel that universities modelled positive and productive career-related employment practices in that they felt that their university careers were largely unsupported and unadvised. As with the other findings, this outcome was consistent with what has been previously published in the literature; furthermore, there is an urgency to rectify this career-related shortcoming.

Based on the results and analysis, six recommendations have been articulated. The final recommendation was articulated to address the challenge of career supports to casual academics (regarding university as employer of graduates) and the other five address the other key student and graduate identified university student experience 'deficiencies' in the context of career development.

- Create a Graduate Employability Portfolio whereby it is a leadership responsibility to build connections and capacity between: Marketing/Student Recruitment/Enrolment; Faculties and Programmes; University Services; and Alumni Offices.

- Provide regular career development/update sessions including the staff from each of these areas.

- Host regular networking functions between graduated, current and future students, mapping and beginning with the degrees/disciplines where graduate career outcomes are most problematic.

- Create a digital repository of degree/discipline-specific career videos. For example, featuring law graduates - 'I graduated from Law in 20XX and here's what my career looks like. My key advice for Law students if you want to follow a similar path is.....'

- Create a new position in the higher education sector for Career Learning Advisors (CLAs). The CLA's primary responsibility would be to meet with future students to help them connect the dots of the career/study journey. Furthermore, CLAs would have a case management function whereby they would check-in with current students and graduates and facilitate introductions and referrals to personalise further supports and services.

- Formalise a career development support program with a strong component of mentoring to support early career academics and those attempting to transition from the casualstream to progress in quality academic careers.

Notably, students and graduates appeared to unconsciously subscribe to a largely vocational model of university education. Very few students had appeared to examine whether or not it is the role of universities to prepare students for future careers. There appeared to be a nearly unanimous notion that career preparation was the main, if not sole, purpose of university. Furthermore, while students criticised university career services and provided recommendations for improvement, there appeared to be an unquestioned belief that the current structures are the only possibility for career services. In other words, there was nearly no mention of whole-of-university responsibility for career development nor embedding graduate employability into curriculum and assessment.

Kinash, S., Crane, L., Capper, J., Young, M., \& Stark, A. (2017). When do university students and graduates know what careers they want: A research-derived framework. Journal of Teaching and Learning for Graduate Employability, 8(1), 3-21. 18 
A limitation of this research was that it was cross-sectional; for further research, it is suggested that individual students are followed through their career choice journeys in a longitudinal manner. Furthermore, the disciplinary sample sizes were not large enough to compare career choices across disciplines, suggesting another basis for further research. Despite these limitations, a range of factors influencing career perceptions and decisions have been identified and woven into a practical framework from which support strategies can be drawn. A critical element at all stages is communication - without clear direction that career intentions and outcomes are an integrated element of a course, students may not understand the implications of the information and may not take maximal advantage of the opportunities.

Kinash, S., Crane, L., Capper, J., Young, M., \& Stark, A. (2017). When do university students and graduates know what careers they want: A research-derived framework. Journal of Teaching and Learning for Graduate Employability, 8(1), 3-21. 19 


\section{References}

Alvesson, M., \& Sköldberg, K. (2000). Reflexive methodology: New vistas for qualitative research. Thousand Oaks: Sage.

Bennett, D., Richardson, S., \& MacKinnon, P. (2015). Enacting strategies for graduate employability: How universities can best support students to develop generic skills: Final report. Sydney: Australian Government Office for Learning and Teaching.

Borg, T., Bright, J., \& Pryor, R. (2006). The butterfly model of careers: Illustrating how planning and chance can be integrated in the careers of secondary school students. Australian Journal of Career Development, 15(3), 54-59. doi:10.1177/103841620601500311

Brewer, M., Flavell, H., Harris, C., Davis, M., \& Bathgate, K. (2014). Ensuring health graduates' employability in a changing world: Developing interprofessional practice capabilities using a framework to inform curricula. Journal of Teaching and Learning for Graduate Employability, 5(1), 29-46.

Brown, R., \& Carasso, H. (2013). Everything for sale? The marketisation of UK higher education. London: Routledge.

Caballero, C., \& Walker, A. (2010). Work readiness in graduate recruitment and selection: A review of current assessment methods. Journal of Teaching and Learning for Graduate Employability, 1(1), 13-25.

Creed, P.A., \& Hughes, T. (2012). Career development strategies as moderators between career compromise and career outcomes in emerging adults. Journal of Career Development, 40(2), 146-163. doi: 10.1177/0894845312437207

Daghbashyan, Z., \& Hårsman, B. (2014). University choice and entrepreneurship. Small Business Economics, 42, 729-746. doi: 10.1007/s11187-013-9501-0

Dias, D. (2011). Reasons and motivations for the option of an engineering career in Portugal. European Journal of Engineering Education, 36(4), 367-376. doi: $10.1080 / 03043797.2011 .593096$

Ellis, C., Kiesinger, C., \& Tillman-Healy, L. (1997). Interactive interviewing: Talking about emotional experience. In R. Hertz (Ed.), Reflexivity and voice (pp. 119-149). Thousand Oaks, CA: Sage.

Giles, M., Ski, C., \& Vrdoljak, D. (2009). Career pathways of science, engineering and technology research postgraduates. Australian Journal of Education, 53(1), 69-86. doi: 10.1177/000494410905300106

Jollands, M., Clarke, B., Grando, D., Hamilton, M., Smith, J., Xenos, S., Carbone, A., Burton, L., Brodie, M., \& Pocknee, C. (2015). Developing graduate employability through partnerships with industry and professional associations: Final report. Sydney: Australian Government Office for Learning and Teaching.

Kinash, S. (2006). Seeing Beyond Blindness. Greenwich, Connecticut: Information Age.

Kinash, S., Crane, L., Judd, M-M., Mitchell, K., McLean, M., Knight, C., Dowling, D., \& Schulz, M. (2015). Supporting graduate employability from generalist disciplines through employer and private institution collaboration: Final report. Sydney: Australian Government Office for Learning and Teaching.

Oliver, B. (2015). Redefining graduate employability and work-integrated learning: Proposals for effective higher education in disrupted economies. Journal of Teaching and Learning for Graduate Employability, 6(1), 56-65.

Pryor, R. G. L., \& Bright, J. (2003). The chaos theory of careers. Australian Journal of Career Development, 12(3), 12-20. doi:10.1177/103841620301200304

Kinash, S., Crane, L., Capper, J., Young, M., \& Stark, A. (2017). When do university students and graduates know what careers they want: A research-derived framework. Journal of Teaching and Learning for Graduate Employability, 8(1), 3-21. 20 
Shaddock, A. (2014). Using data to improve learning: A practical guide for busy teachers. Camberwell, VIC: ACER.

Sornapooman, K., \& Fyfe, G. (2015). Exploring the outcomes of BSc Human Biology graduates and their perceptions of the course. Journal of Teaching and Learning for Graduate Employability, 6(1), 24-43.

van Manen, M. (1997). Researching lived experience: Human science for an action sensitive pedagogy. London, Canada: Althouse.

Wu, Y-L., Tsai, Y-L., \& Chen, C-W. (2014). Examining the experiences of career guidance, vocational self-concept, and self-perceived employability among science education majors in Taiwan. Journal of Baltic Science Education, 13(2), 182-190. 